\title{
Visions and Challenges of Payday Lending in Lithuania
}

The paper provides systematic view on payday lending in Lithuania, joining legal and economic approaches. Institutions of credit access as a human right per se, responsible lending and usury are conceptually analysed, defining theoretical visions and methodological challenges, that persist in search of fair balance between the need of borrowers and the greed of lenders at payday transactions.

Keywords: payday lending, credit access, human rights, dignity, adequate standard of living, responsible lending, usury, transaction cost, over-indebtedness, process mining, debt to income ratio

Straipsnyje pateikiamas sisteminis požiūris ị mažuosius vartojimo kreditus Lietuvoje, apimant teisinị bei ekonominį aspektus. Konceptualiai analizuojami kredito prieinamumo kaip žmogaus teisès per se, atsakingo skolinimo ir palūkanų institutai, išskiriami teoriniai požiūriai ir metodologiniai iššūkiai, kylantys, ieškant teisingos pusiausvyros tarp skolininkų poreikių ir kreditorių godumo mažojo vartojimo kredito sandoryje.

Raktiniai žodžiai: mažasis vartojimo kreditas, greitasis kreditas, kredito prieinamumas, žmogaus teisé, orumas, pakankamas pragyvenimo lygis, atsakingas skolinimas, palūkanos, sandorio sąnaudos, prasiskolinimas, proceso gavyba, skolos ir pajamų rodiklis.

\section{Introduction}

The payday lending market has emerged and has been rising rapidly in Lithuania as the result of sudden increase of liquidity concerns and restricted access to the mainstream credit at the peak of overall economic hardship in 2008-2009. Despite the tremendous popularity, the payday loans have earned a bad name mostly because of charges on immoral and irresponsible lending, decorated by the horror stories of loans-gone-wrong. As a response to public charges and regulation initiatives, the industry has tried to justify itself with high transaction costs and benefits of having the lender of last resort available to the consumer in need.

In other words, the problem of payday lending arises from the classical and natural tension between the need of access to credit, with the peak importance to the poor (the Need), and the greed of the financial institutions (the Greed). The Need and the Greed are (have always been) the

Valdonė DARŠKUVIENĖ - Doctor of social science, professor at the Department of Finance, the Faculty of Economics and Management, Vytautas Magnus University, Lithuania. Address: S. Daukanto St. 28, Kaunas, Lithuania; Phone: 0037037 327856. Fax: 0037037 327857. E-mail: v.darskuviene@evf.vdu.lt.

Paulius ASTROMSKIS - PhD student at the Department of Finance, the Faculty of Economics and Management, lecturer at the Faculty of Law, Vytautas Magnus University, Lithuania. Address: S. Daukanto St. 28, Kaunas, Lithuania, Phone: 0037037 327856; Fax: 0037037 327857; E-mail: paulius@astromskis.lt. 
yin and yang of consumer finance. This tension has attracted attention not only from media and regulators. The scholars worldwide found many challenging fields for theoretical and empirical research. Yet, the payday lending phenomenon, although over-controversial, is well under-explored, especially in the Lithuanian context.

Motivation to write this paper is primarily methodological. This paper discusses responsible lending and usury in the field of consumer credit, theoretical visions and methodological challenges, that persist in search of fair balance between the need of borrowers and the greed of lenders at payday transactions. The major legal, economic and organizational challenges are left for further theoretical treatment and empirical proving. Our task here is to propose an analytical approach to the credit access issues and to describe briefly the Lithuanian context for further empirical testing. Therefore this paper contributes to the knowledge, wisdom and understanding of fair balance between the Need of borrowers and the Greed of lenders.

With regard to the Need side of our paper, we ask whether the access to credit should be recognized and treated as The Human Right per se. Following the poverty alleviation approach of the Nobel Prize laureate Muhammad Yunus (2006), we look for answers in the wellestablished principle of inviolability of human dignity and guaranteed adequate standard of living. Although not without opposition, we find strong arguments supporting our proposition that poor household has the strong claim to benefit from the credit as the right. Further, after having briefly described the situation in Lithuanian households we find a trou- blesome set of financial situation ratios which, in our opinion, explains the reasons of payday loans popularity and proves that access to credit is more important than its price.

With regard to the Greed side of our paper, first of all we extract two sub-issues of responsible lending and usury, and proceed with the discussion of them separately. As we have found the wellrecognized problem of definition and measurement of over-indebtedness, we have chosen the subjective approach to definition and we offer the process mining techniques as a possible measurement solution. With regard to the usury, we find it to be a binary problem too, with the transaction cost on one hand and tolerable rate of interest, on another. Using the logics of transaction cost theory, developed by two Nobel Prize laureates R. Coase (1937) and O. E. Williamson (1975), we describe briefly the major variables and approach to measurement of ones. With regard to the tolerable rate of interest, we criticize the flat fit-for-all rates and support the procedural fairness approach, although once again - not without opposition. Further we brief the major financial ratios of the payday lenders, showing on the side of it some insights into the media and regulatory perception. Afterwards the conclusions follow.

Thus, the aim of this paper is to propose an analytical approach to the credit access issues in the context of payday lending market in Lithuania. The research questions we explore in this paper are: whether access to credit should be the Human Right per se? How to ExAnte evaluate the ability to pay ExPost, and where the limit separating sustainable amount of debt and over-indebtedness of 
a borrower is? At what rate usury should be tolerated? Research methods are based on literature review, thus contrasting different approaches to selected credit access issues, which are divided into two major groups - the need of borrowers and the greed of lenders. Based on statistical data analysis, the context of payday lending in Lithuania is explored and presented.

\section{The Need}

We, the People ${ }^{1}$ of the market economy, in order to promote general welfare to ourselves and our posterity, have to consume. Globalization, acceleration of consumption and growth of transactions thereof, had resulted in substantial increase in the household debt and decrease in savings ratio ${ }^{2}$. Consumer credit has become a common source of finance for households (Betti, Dourmashkin, Rossi, \& Yin, 2007). Therefore being indebted is normal consumer behavior, inevitable for the majority of households (European Commission, 2001, 2008, 2010). The importance of credit on the household welfare had even triggered the discussion whether access to credit should be the Human Right ${ }^{3}$. That is, the credit transaction has been elevated to the highest level of social analysis, institutions of which, according to O. E. Williamson (1998, 2000), are changing "very slowly on the order of centuries or millennia" 4 .

It is worth to explain for ones who don't have legal training that the Right of one defines the Duty to be obeyed by others, who are in the field of that Right, and vice versa. This leads to bilateral relationship as a unit of analysis. Moreover, according to A. Vaišvila (2004), it results in two major regulatory constrains: (i) the right shall not be denied without sufficient cause and fair procedure, which suggests the necessity for carefull evaluation before restrictive rulemaking; and (ii) the realization of right shall be guaranteed by the force of the State, which suggests the necessity for accessible and error-free enforcement institutions.

From the perspective of the borrower it means that the right to borrow defines the duty to lend. Therefore the borrower should benefit from the following set of outcomes: (i) access to credit cannot be denied without sufficient cause and fair procedure; and (ii) realization of the right to credit shall be warranted by the force of the State. From the perspective of the lender it means that the duty to lend defines the right to claim repayment (plus usury). Therefore the lender should equally benefit from the same set of outcomes: (i) the right to claim repayment shall not be denied without sufficient cause and fair procedure; and (ii) the realization of the right to repayment shall be warranted by the force of the State. From the perspective of the State it means that: (i) it has to make regulatory choices to ensure the fair and effective balance of rights and duties between the parties in credit transaction, and (ii) to provide equally accessible and error-free enforcement services.

In order to grant the access to credit a status of the Human Right, one has to find an authority either in metaphysical absolute or in the will of the regulating bodies. The former would satisfy natural law approach, while latter - positive law (Weissbrodt et al., 2001). It should be noted, however, that neither of general human rights treaties clearly states that 
access to credit should be a Right per se. One of supporting arguments might be found in the principle of inviolability of human dignity, which is firmly anchored in all major human rights treaties and Constitutions ${ }^{5}$ drafted in the spirit of Nuremberg Trials. These documents are held to be an expression of the natural law through the written word of human being (McDougal et al., 1977). That is, inherent dignity of all human family members is a well-accepted right by both approaches to the human rights. Following this string of legal analysis, the issue is whether access to credit is indispensable from the dignity of all human family members.

It is a Nobel Peace Prize honored fact that welfare may be increased (and poverty reduced) directly through greater access to credit (Yunus, 2006). In M. Yunus' opinion, the access to credit is intimately linked with the pursuit of well recognized basic human rights: food, shelter, healthcare, education, work and alike, and therefore provides "a comprehensive set of rights" (Hudon, 2009). This argument finds its authority in Article 22 of UDHR, which directly links social security, economic, social and cultural rights with the concept of dignity, and Article 11 of ICESCR, which guarantees the right to "an adequate standard of living for himself and his family". Following this string of logics, the core issue is what "adequate" stands for. Does Tarzan have the legal right to the same standard of living as Jane Porter, or maybe the latter is significantly over-consuming? Who and how should determine it? These and many more questions arise from such highly hermeneutical obligation imposed on the society.
Despite the width of the definition, its identification is relatively simpler. First of all, one has to form the hypothetical budget of household, which is needed for adequate standard of living, i.e., minimal rate of consumption. In our opinion, this budget should necessarily include at least these goods and services. which are expressly listed in Article 22 of UDHR, Article 11 of ICESCR, Article 27 of CRC, Article 28 of CRPD: (i) food, (ii) clothing, (iii) housing, (iv) continuous improvement of living conditions, (v) goods and services needed for the child's physical, mental, spiritual, moral and social development (for households with children).

The second step in the analysis is to inquire whether the household may achieve at least the level of "tolerable income" (Posner, 2003) without access to credit. If the regular income or assets of a household are not sufficient to reach the adequate standard of living, the society has to face the issues of poverty and costs of its reduction (Posner, 2003). Having limited scope of alternatives, the financially excluded poor have to increase income, use or otherwise dispose the assets, borrow or turn towards an opportunistic behavior. Since the opportunistic behavior diminishes general welfare and is generally illegal it should not be proposed as an acceptable alternative of action. Therefore the under-consumed household should turn to the remaining three alternatives. The rights to income and control of assets are defined primarily by the well established rights to labor and private ownership. If these two are not sufficient to ensure the adequate standard of living, the access to credit as a single choice left, should be treated as the right. That is, the bigger gap between 
adequate standard of living (minimum rate of consumption) and capacity to ensure it through labor or control of assets is the stronger is the case of the Human Right to credit per se.

Intuitively the conclusion may be made that the lesser income or assets a household has, the higher is its demand for credit, if the adequate standard of living remains stable. However, households adjust their standard of living to fit their consuming capacity up until some lowest limits below which human dignity is being undermined. That is, facing the decrease in the income or assets, a household may make a decision to lower the level of living. This set of decisions is available only up to some bottom limit of living conditions, below which inability to consume damages person's dignity. This is the threshold of poverty, i.e., field where restriction of access to credit should be very well and carefull weighted. Households at this threshold have the strongest claim to credit as the Human Right per se. Moreover, such poverty alleviation approach makes the access to credit partly a social mission to protect the dignity of the poorest households, not only a business mission to expand the consumption.

Of course, this bottomline concept is very context-sensitive and may be constructed only after identification of particular society and characteristics of its individual households thereof. Briefing the Lithuanian context, the financial situation of $38 \%$ households was very difficult or difficult in 2011 (Statistics Lithuania, 2011). It is expressly stated that the income of $56 \%$ households was lower than expenses needed to ensure the adequate standard of living. This ratio is $74 \%$ for single-parent households (one parent and one child) and $72 \%$ for single households. Moreover, $42.4 \%$ of single households with children, $10.1 \%$ of the employed and $53.1 \%$ of the unemployed households are at the risk of poverty. More than $60 \%$ of households would not be able to cover $830 \mathrm{Lt}$ (240 Eur) of unexpected expenses.

This partially explains the rise and tremendous popularity of the highly accessible $^{6}$, but the most expensive and controvercial payday loans ${ }^{7}$. The sudden increase of liquidity concerns and restricted access to mainstream credit at the peak of overall economic hardship in 2008-2009 has created the perfect market place for the third-tier lenders. 17 out of 27 active companies ${ }^{8}$ offering payday loans were established during these two years9. In 2011 the portfolio of payday loans expanded by more than $80 \%$ (Bank of Lithuania, 2012) and the annum was celebrated by the industry with the overall revenues from interest of more than $100 \mathrm{mln}$. LTL. The industrial growth slowed down in 2012, still the portfolio expanded by $32 \%$ (Bank of Lithuania, 2013). In 2012, top 3 payday lenders ${ }^{10}$ alone reported more than $102 \mathrm{mln}$. LTL of revenues. Although the full annual review has not been reported yet, the overall market in 2012 might reach $130 \mathrm{mln}$. LTL.

Although, comparing to the mainstream lending, these are relatively small numbers, and the frequency of transactions is very high. The price of average credit is approximately 151 LTL ( 44 EUR). It means that in order to reach the $100 \mathrm{mln}$. LTL threshold, the consumers had to take (or rollover) approximately 667.000 times per year (6 loans every 5 minutes). It is 27 loans (or rollovers) for every 100 persons of legal 
age (18 and more). With the frequency of more than 861.000 payday transactions (loans or rollovers) per 2012, these rates are accordingly -36 transactions for every 100 persons, and 8 loans every 5 minutes.

Moreover, the recent survey of payday borrowers conducted by RAIT (2013), has showed that three most popular usages of payday loans were: (i) to pay for household expenses (28\%), (ii) to pay utility bills (24\%) and (iii) to buy food $(21 \%)$. That is, the most popular usages are all linked to the most basic human needs. Most of the times, the access to this kind of credit is the irreplaceable source of finance for these households, most of which are low income and young households (Bank of Lithuania,

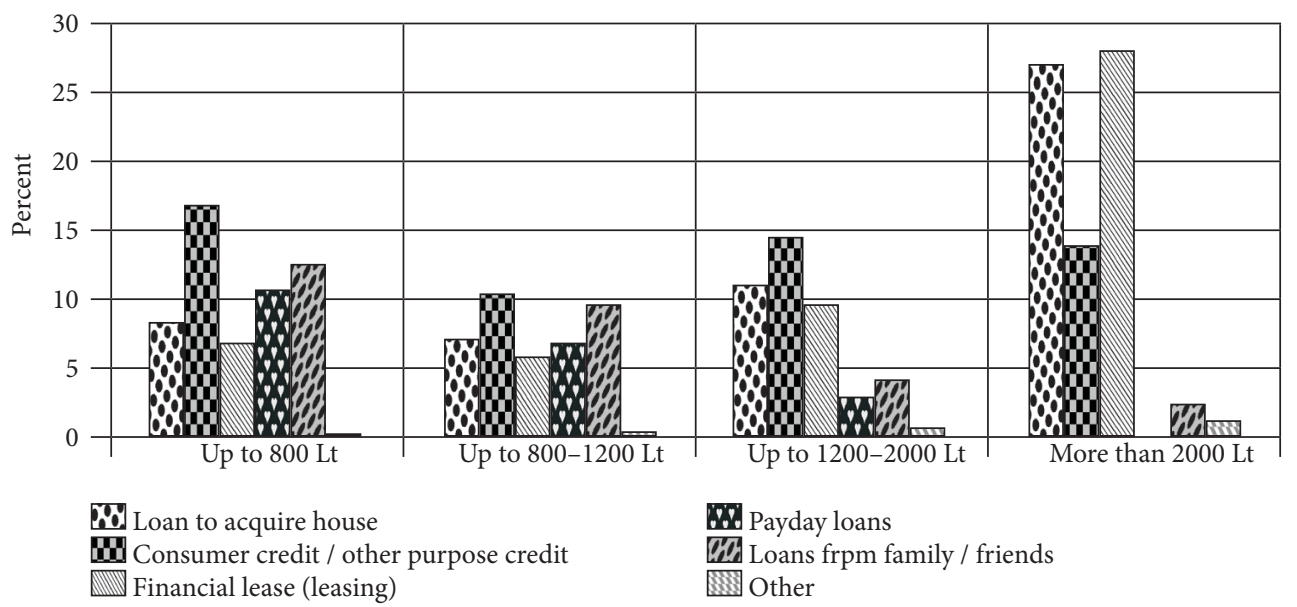

Fig. 1. Types of financial obligations (by the income to one member of a household) (percent, comparing to the same income group) in Lithuania

Source: Bank of Lithuania (2012, 2013).

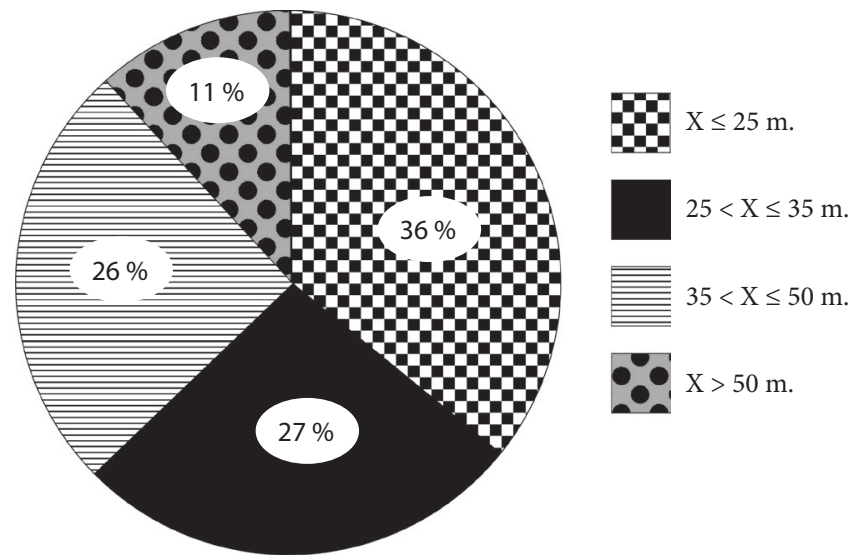

Fig. 2. Distribution of consumer credit users by age in Lithuania 
2012). $63 \%$ of the borrowers are under the age of 35 and this source of finance is common in the households with less than 1200 LTL ( 347 EUR) of monthly income (see Figures 1 and 2).

The obvious importance of the access to credit for the Lithuanian households seems to warrant the recognition of The Human Right to credit and pressure on the governments to take appropriate steps to ensure and protect the realization of it. In support of this argument it should be noted that there is a clear scientific evidence supporting the existence of a liquidity constraint, severer and more widespread over-indebtedness, where consumers have less access to credit market (Betti et al., 2007). Moreover, it is scientifically proven facts that: (i) restricting access to expensive credit harms consumers on average (Zinman, 2010); (ii) limiting access to credit may make some people considerably worse off (European Commission, 2001); (iii) problems of managing debt, and of covering the costs of servicing loans, are likely to increase rather than diminish if there is a cutback in credit (European Commission, 2010); (iv) access to expensive consumer loans helps borrowers smooth negative shocks, better manage liquidity and alleviate financial distress (Morse, 2011; Wilson et al., 2010; Morgan, Strain, 2008); (v) access to credit makes significant and positive effects in job retention (Karlan, Zinman, 2010); and etc.

Honoring the opposition, there are none the less important arguments against elevation of credit into this metaphysical level. First of all, as it has been already mentioned above, the right to credit implies the duty to provide it. Therefore in the society governed by the principle of inviolable private ownership, the issue of fairness and efficiency to demand exchange of cash for mere promise with everybody (especially the poor) is at stake (Hudon, 2009; Nozick, 1974; Sen, 2009). That is, who would be responsible for fulfilling this right? Will the profit seeking credit institutions be willing to cooperate voluntarily, or should government force them to credit those that they otherwise would not? Or maybe the right to credit should be implemented by some special government institution? Moreover, as J. Gershman and J. Morduch (2011) have correctly pointed out, the questions of price, duration and scale of access are even more contentious. Despite the difficulties, in our opinion, these are procedural issues, which shouldn't quash the existence of the right provided it exists. The members of the human society shouldn't be able to overrule the divine will simply because it is too hard to realize.

Secondly, as we have mentioned before, the right to receive credit implies the duty to repay principal and usury (interest). If the transaction is voluntary, the profit seeking lender will be willing to lend only if the interest overweight the risks of the transactions. It means that the price of credit for the poor household will be relatively high. Accordingly, the higher the price of credit is, the higher is the risk of default and hence the result will be harsh repayment process, which is directly linked with the threat of opportunism, over-indebtedness, debt-cycling, rollovers and other events that exacerbates financial distress (Bhutta et al., 2012; Carrell, Zinman, 2008; Melzer, 2009; Zinman, 2010, and others).

If a household makes an error either in the valuation of consumption benefits or the capacity to repay debt with usury, repayment process may be harmful 
to the household. Since individuals "often make serious mistakes in deciding important matters" (Epstein, 2006), the paternalistic intervention restricting access to credit may prevent such household from harming itself and therefore be justifiable. However, ones that are most susceptible to credit exclusion are once again the poor households. That is, the ones that have the biggest claim to have right to credit, bear the highest risks to be harmed by that same right.

The question, however, as correctly pointed by (Bar-Gill, 2007) "is not whether individuals make mistakes. Sure they do. The question is whether these mistakes merit legal intervention". That is, whether government a priori knows better what is best for the poor, or should the poor be left with a chance to decide by themselves. The borrower may be a loan-short of finding the solution for indignity threat and inevitable harm thereof. The error in preemptive restriction of access to credit for the poor households may be as harmful as over-indebtedness: shadow borrowing, opportunistic activities, crimes, divorces and depression with its extreme suicidal form. If the civil society is based of presumption of bonus pater familias, the household should have the chance to make mistake, since most of the prudent households will not make one. However, if the regulator thinks of household head as of stupidus pater familias, the outcome is of course the opposite.

Thirdly, one may argue that with the same success we may say that the credit is intimately linked with the pursuit of all and any of human rights. Indeed, there is no single right that may be implemented or protected without any direct or indirect financial support. However, such fit-for-all view does not diminish the importance of credit. On the contrary - it is an argument that advocates of the right to credit well underestimate it.

In summary, debt is an inevitable part of welfare discourse. The credit has become a normal consumer behavior, common and inevitable source of finances for households. Moreover, at some point of under-consumption, the accessibility of credit may be regarded to be The Human Right with the respective duties implied on lender and the State. We find an authority for such conclusion in the well-established concept of human dignity and guaranteed adequate standart of living thereof. If, after the analysis of household needs and means to satisfy them, it appears that the level of income and assets possesses the threat of indignity, that household has the strongest case to benefit from the Right to credit. The financial situation of the most Lithuanian households is exactly at this threshold. In other words, the Need of credit seems to warrant the recognition of The Human Right to credit and pressure on the governments to take appropriate steps to ensure and protect the realization of it. Accordingly, the access to credit deserves special scrutiny and very careful regulation in order to avoid unreasonable and severe consequences of legislative error. However, the opposition of this approach raises some important and meaningfull issues, which have to be solved. Recognizing the bilateral nature of transaction and bounded rationality of consumer, some restrictions to access of credit may indeed protect the households from overindebtedness. Having it said, we shall proceed with the discussion on the other side of a coin - the Greed of lenders. 


\section{The Greed}

We, the People of the market economy, also suffer from imperfect rationality, impatience, overoptimism, overconfidence and other behavioral anomalies (Fritzdixon et al., 2013). The simplicity of access to credit makes the tradeoffs of the hausehold more susceptible for errors. However, this will usually be appearant to the borrower only after the lapse of time. Facing the choice to increase the consumption capacity (receive benefits today) and to pay later (bear the costs in future), some of the population will inevitably make mistake. The problem, however, lies not in the natural human nature to err. Rather it is in some of the lenders' strategic response to these errors.

Some lenders, infected by the sin of the Greed, knowingly exploit these behavioral anomalies or the borrowers' dire need of funds. The excessive profiting from current Needs, disregarding the future consequences, might harm household more than under-consumption or financial exclusion. The surplus of debt burden, i.e., over-indebtedness, seems to mandate the paternalistic intervention into the credit transaction in order to push the household towards the saving or asset management strategy it would never come-up with having the free access to credit. On the other hand, as we have noted before, access to whatever expense credit might be the last chance to buffer the impacts of negative shocks and stabilize the debt servicing capacity of household. Suddenly unemployed Joe may need a tank of gas to go for job interview and hold-on just until payday; or suddenly ill Mary may need some medical intervention in order to recover her working capacity. Therefore paternalistic restrictions of access to credit might harm those, who act responsibly and rationally.

Thus, the task of balancing the Need and the Greed is a twofold. From one side, the access to credit shall not be restricted to ones who has priority $\mathrm{Ne}$ eds and borrow in order to avoid indignity threat and to restore consumption capacity. On the other hand, the credit access regulation should discipline lenders to prevent over-indebtedness and ban the immoral profiting. To put it in other words, the questions are whether it is fair to deny credit to particular borrower and if the credit should be provided, how much it is fair to charge for it. Accordingly, susceptible to this regulation there are the fields of responsible lending and usury. The former should ensure the accessibility of data for future projections, while the latter should protect from immoral profiting.

With regard to the responsible lending, the issues are how to ExAnte evaluate the ability to pay ExPost, and where the limit separating sustainable amount of debt and over-indebtedness of a borrower is. These are tough and challenging issues, since as G. D’Alessio and S. Iezzi (2013) notes, there is no consensus in the literature on the definition of overindebtedness or, consequently, on how to measure it. The same conclusion has been made by various studies conducted by the European Commission (see 2001, 2008, 2010). In this regard G. Betti et al. (2007) distinguish the main indicators of indebtedness ${ }^{11}$ used by various organizations, which are mostly devised to compare debt with assets of the borrower either in objective, subjective or administrative models. However, this study 
aligns with the above mentioned conclusions that there is no methodology for determining the critical level of these ratios and all of them suffer from the information deficit.

Of course, a regulator may take a quick and easy path defining a "fit-for-all" indicator (e.g., debt to income, debt to asset, etc.) and prohibit transactions which are below some flat rate, hoping that the average benefits will outweight harm to the general welfare. However, such type of rulemaking unnecessarily restricts the access to credit for some borrowers, violates consumer's freedom of choice, and is a form of hard paternalism (Meade, 2012). Moreover, the flat objective rates usually ignore the capacity of younger families to accumulate more debts than it can repay and thus ensure the steady living conditions (Modigliani, Brumberg, 1954, 1990; D’Alessio, Iezzi, 2013). Having in mind that certain level of debt is inevitable for the majority of households, particularly at the earlier stages of their lifecycle, the financial exclusion based on average rates cannot be easily justified. In addition, all of these rates have their individual shortcomings. For example, pure objective debt-to-income ratio (or its variations) ignores assets and savings, which are directly linked with the capacity to service a debt promise. Accordingly, it is well recognized that such ratios do not necessarily reflect the financial position of individual households (European Commission, 2010).

The European Banking Industry Committee (EBIC) (2011, 2012) also supports the proposition that there is no 'one size fits all' figure which could be appropriate to describe over-indebtedness for each and every borrower. According to the European Commission
(2001, 2008, 2010), the level of debt, at which a household becomes over-indebted, depends on many factors: the size and structure of the debt, the debt-servicing arrangements, the assets of the household, other personal and economic characteristics of the household, as well as external factors such as the state of the economy. Thus the critical level of debt differs between households and there cannot be objective, single fit-for-all ratio defining sustainable level of debt at all stages of life.

It seems, therefore, that the most straightforward and powerful method of determining the over-indebtedness is to ask the household directly whether or not they are facing debt repayment difficulties (Betti et al., 2007; D’Alessio, Iezzi, 2013). Generally people do not attempt to hide their difficulties (European Commission, 2001), therefore the Commission has offered the pure subjective definition of over-indebtedness: "[a] person is over-indebted if he or she considers that he or she has difficulties in repaying debts, whether consumer debt or a mortgage".

We adhere to this definition, although in recent study the European Commission (2010) has recognized that it is problematic when it comes to measurement. In our opinion, if the definition is correct, the measurement problems should challenge the creative minds, not quash the definition. The exponential growth of the "digital universe" and technology makes it possible to record and analyze events at the nano level of objective events and subjective activities. The challenge is to capture the data and extract the knowledge out of the chaos of the event logs. Hawing the detailed past and present data on events and activities of the household (e.g., transactions, applications 
for medical care, browsing history, etc.), the credit scoring might be developed to perfection, by providing subjective evaluation from objective data. This is the wide field of process mining techniqu$\mathrm{es}^{12}$, as manifested by W. M. P. Aalst et al. (2012) and extensivelly described by W. M. P. Aalst (2011).

The second part of the Greed problem - usury - has evolved throughout millennia and has "absorbed the minds of some of history's greatest thinkers" (Bodenhorn, 2005). Aristotle, Aquinas, Locke, Smith, Bentham, Keynes and many other academic superstars are just a few to mention. Throughout history usury was commonly viewed as intrinsically evil and immoral (Rutherford, 2005; Voth, Temin, 2004). However, as market economies evolved, the notion of usury has changed from whether usury was acceptable to how much it was tolerable (Peterson et al., 2008; Rutherford, 2005). Hence, various usury laws came into fashion.

Usury caps are established to curb power of lenders, to protect naive borrowers, to discourage profligacy and to influence the allocation of resources (Bodenhorn, 2005). On the other hand, it is argued that usury laws actually make high-risk or low-wealth borrowers worse off because they are either excluded from regulated credit markets, deprived of the ability to build a credit history, or they are driven into the hands of loan sharks with questionable methods of providing or enforcing credit (Reifner et al., 2009; Rigbi, 2009). Moreover, the access to cheap credit gives no incentive to save and restricts development of the financial infrastructure (Hudon, Sandberg, 2011). In our opinion, the policy decisions with regard to tolerable rate of usury should fairly balance between the welfare of the customers on the one side, and the imperative of building strong institutions on the other. That is, the interest rates should maximize the overall utility, be mutually fair (in legal terms) or $^{13}$ effective (in economic terms). The issue, however, remains - how much is too much?

M. Yunus (2006), as observed by M. Hudon and J. Sandberg (2011), has a straightforward and simple approach to this issue. He separates the costs of credit transaction from its premium and argues that interest rate is reasonable if it does not exceed the necessary cost of funds by more than $15 \%$. Following the logics of separation costs from premium, the task for the regulatory seems to be the development of the transaction so as to economize on its costs as much as possible. The reduced transaction costs would result in decreased price of credit, provided the premium stays capped.

The logic of transaction cost analysis and economization thereof is still under development in the field of Transaction Costs Economics (Williamson, Tadelis, 2012). Started and developed mainly by Nobel Laureates - R. Coase (see 1937, 1960 for example) and O. E. Williamson ${ }^{14}$ (see 1975, 2000 for example), the Transaction Cost Economics have become an "empirical success story" (Williamson, 2000) and one of the dominant economic theories of the XXI century (see Carter, Hodgson, 2006; Geyskens, 2006; Macher, Richman, 2008; Ruester, 2010, and others). According to this theory, as we interpret it, the state of zero transaction cost may be reached only if all promises (including implied promise of good faith and fair dealing) are kept, i.e., when ownership is perfect. 
However, it is not a case in the market economy, highly infected by the sins of malice. A promisee is always at risk that a promise given to him/her will differ from the true will or the true actions of the promisor. That is, there is always a risk of asymmetry between the ExAnte promised and ExPost received value of the promise. In order to protect him/ her from the perils that the promise will be breached in the future, the promisee invests in pre-contractual research, drafting of contract and the protective means thereof. That is, some costs of transacting are incurred ExAnte.

However, all of the means employed at this stage are based on assumptions about future events, which are impossible or too costly to determine with certainty. Of course, the more investments are made at the pre-contractual stage, the less is the risk of post-contractual breach. However, human body and mind have their limits, which together with future uncertainty make it impossible to determine all the sources of risk and employ preemptive means to avoid them. Moreover, pre-contractual investments are inevitable and future risks are only probable. Besides, every symbol used in drafting has its own hermeneutical risk, which might be the source of misinterpretation and hence error in the enforcement procedure. Due to these shortages, the parties may "agree to disagree" (Ben-Shahar, 2004). Thus, the contracts are incomplete (see: Eggleston, 2000; Hart, Moore, 1999; Hill, 2009; Posner, 1999; Posner, 2004; Rasmusen, 1995 for egzample).

Therefore, since all transactions have their gaps and are subject to uncertainty, opportunistic behavior of promisor and enforcement errors, the fair balance of rights and duties between parties might be breached. If ExAnte means of protection fail, the parties are forced towards the process of adaptation, compensation or litigation. However, the promises to adapt, to pay damages and to litigate are all the promises susceptible for breach per se. Moreover, neither of these procedures is costless. In any of the scenarios the parties suffer from asymmetry in the timing or value of the expected fruits of trust. These are the ExPost transaction costs.

Adapting the famous formula of Richard A. Posner (2004), where Transaction Costs (TC) are the sum of ExAnte costs $(x)$ and risk $(y)$ that ExPost costs might occur, this might be expressed as simple as:

$$
T C=x+y * z
$$

In the ideal world, everybody keeps his/her promises $(y=0)$. In this case $y^{*} z=0$. Accordingly, there is no need of safety measures. Accordingly, $x=0$ and $T C=0$. Hence, transactions are self-enforcing; the demand for regulation and enforcement services disappears. The market is perfect. However, in the real world the promises are sometimes breached $(y>0)$, and transactions are not self-enforcing. The promisee is always at the mercy of promisor. Accordingly, $y * z>0$. At the face of threat, the demand for protective measures arises. Thus $x>0$, and $T C>0$. It follows that the difference between the ideal and real world is the costs of trust failure.

Accordingly, the major task of regulation is to protect the promisee from the uncertainty and opportunistic behavior in all the stages of transaction. With regard to ExAnte, it implies the duty to 
foster access to data and process mining technology to process it (thus diminishing perils of uncertainty and bounded rationality), and with regard to ExPost the duty to foster accessibility to enforcement system and technology to process the claims (thus diminishing the perils of opportunism and asset specificity).

Having it said, we may turn to the surplus of transaction cost, that is, price of credit. In our opinion, the straightforward application of M. Yunus (2006) usury cap may have a diminishing effect on the accessibility of credit, especially to the poor. Naturally, a poor borrower bears higher risk of default. The creditors, therefore, will be willing to accept high risk either through higher premium, or through distribution of risk among bigger number of borrowers. If the former is capped and capacity to lend stays the same, the latter may be achieved only by lowering the sum of credit and/or shortening its term. However, the administrative and transactional costs associated with the management of large amount of small loans may be immense. Therefore even if the demand is high, there may be no lenders who would be willing to supply a high risk small loan to ones who have the biggest needs.

Besides, according to the law of diminishing marginal utility, poor people may accept higher interest rates than non-poor, since one monetary unit has more intrinsic value to the poor than non-poor (Hudon, Sandberg, 2011). Accordingly, some would-be borrowers might be willing to pay higher price which would be treated reasonable, fair and Pareto efficient. Moreover, an overindebted consumer could still keep up with his/her promises by reducing the level of consumption, selling his/her assets or improving his/her income rates, i.e., solving the liquidity constrains during the time bought for the price of credit, or revising its property management strategies. Despite the reasonableness of the decision to borrow at the high margin, willingness and ability to pay, the credit transaction will never commence if there is no one willing to lend. Therefore we argue, that the price of credit should cover the transaction costs and should provide premium that is based on the principle of fairness and subjective willingness to pay, not on flat "fit-for-all" rate.

According to the procedural approach to fairness ${ }^{15}$, the price of credit should be held fair if parties have full knowledge of their options and a free choice between the alternative ways of action (or inaction). Therefore the fairness depends primarily on the free will of the parties, which should be formed and expressed without any unlawful coercion or deceit, through the full disclosure and bargain of equals. Free will should be bilateral and persist throughout all stages of the transaction. The role of regulators, therefore, is to smooth bargaining inequalities and perils of opportunistic behavior between the parties in transaction. Usually this is achieved using mandatory disclosure requirements, bans of unfair contract provisions, rights of premature withdrawal and other.

While criticizing this approach, M. Hudon, J. Sandberg (2011) assume that "borrowers are forced by their impoverished situation as such to do something, well anything, that can bring food to their table". Supposedly it means that the will of the poor most of the time is not free and genuine. However, are there some, well any, borrower who genuinely desires to be enslaved by the 
ties of debt? Or any other person who would in general prefer obligation over right? The credit transaction arises out of the need of, not love for, the debt. Therefore the desirability of credit shouldn't be a threshold criterion in accepting or denying the free-will approach. The real issue with regard to the impoverished is whether such a borrower has something, well anything, in alternative. If any better alternative is available, the task for regulation is in the field of bounded rationality, if not - in asset specificity. That is, even if there was a single lender in the market, the borrower should be able to decide freely to borrow or not, relying on the understanding of the intrinsic value of credit he applies for.

Therefore, similarly to E. Meade (2012) we believe that the best judges of the capacity to service debt are the households themselves. They know better their time preferences, earning, saving and spending plans, liquidity constrains and motives for borrowing. Therefore the objective indebtedness assessment might be inaccurate. It might help to guess whether the borrower is more likely to repay, but they will not answer why he/she will do so. And the latter is the main issue in evaluation of price fairness (Hudon, Sandberg, 2011). Hence, the data of subjective reasoning should also be taken into account and added to the scoring models. Without holistic evaluation of objective and subjective variables, the paternalistic intervention into the liberty of consumer might be unjust, since it will ignore those who act rationally but are desperate (Meade, 2012).

Continuing with the application of these rules in the Lithuanian payday market context, it should be noted firstly that despite the high price, only $7 \%$ of payday loan agreements end in default (Bank of Lithuania, 2012). The low rate of default makes us believe that the cost of credit is compensated by the value of accessibility. Secondly, the administrative costs associated with the management of large amount of small loans are immense. Although top 3 payday lending companies ${ }^{16}$ are based on advance technologies, the average net margin (before taxes) was $30 \%$ in 20092012, although the average APR charged per loan is close to $200 \%$ (see Figure 3).

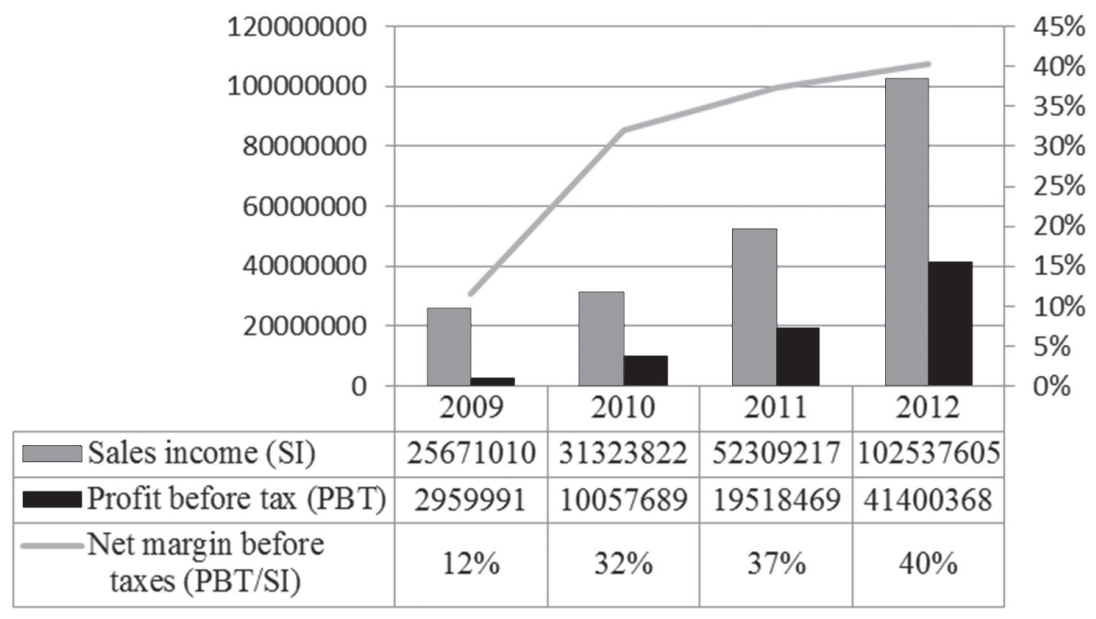

Fig. 3. Key financial data of Top 3 payday lenders in Lithuania 
If we recall the findings in the Need chapter that payday loans are used very frequently by high risk low income and young Lithuanian households, $30 \%$ net margin does not seem to be unfair on its face. Such a conclusion is supported by the fact that these hight-risk households are fulfilling their obligations properly most of the time (93\%).

In summary, we agree undisputedly that people suffer from behavioral anomalies, which are susceptible for exploitation by the greedy lenders. This mandates paternalistic intervention to prevent overindebtedness and immoral profiting from the Need. With regard to the former issue of responsible lending, the major problems seem to be the definition of over-indebtedness and accessibility to subjective data and technology to measure it. With regard to the latter issue of tolerable usury, the major problems are economization on transaction costs and fair surpluss of lender profit. The brief analysis of these issues allows us to agree with the subjective definition of over-indebtedness and offer process mining techniques for extracting knowledge out of the chaos. The applied technology would also benefit in diminishing perils of uncertainty and bounded rationality, thus solving part of ExAnte transaction costs issues, leaving the regulators with the ExPost costs, deriving from the opportunism and asset specificity variables. Finally, we believe that the profit cap above transaction costs should not be a fit-for-all ratio. The market is susceptible to self-regulation and this seems to be proven by the numbers of top 3 companies in a very concentrated payday market. Despite the numerous charges on greedy lending and immoral profiting, the straightforward analysis of the financial data shows the average net margin of just
$30 \%$ above the costs. Accordingly, this leads to discussion on rationality and dangerousness of current legislative initiatives brought by the Lithuanian regulators.

\section{In lieu of conclusions}

As discussed above, the access to credit for households, which are under the adequate standard of living, deserves special scrutiny and very careful regulation in order to avoid unreasonable and severe consequences. The error in preemptive restriction of access to credit for these households may be as harmful as over-indebtedness: shadow borrowing, opportunistic activities, crimes, divorces and depression with its extreme suicidal form.

The situation in the Lithuanian households in this regard is unenviable. The lack of the most basic human Needs has driven them into the hands of payday lenders, who have been growing rapidly in Lithuania since 2008-2009. The obvious importance of emergency credit to the Lithuanian households illustrated by the numbers above leads us to the conclusion that the payday loans might indeed serve as a last chance to survive the financial shocks and indignity threat thereof. This, in turn, seems to warrant the pressure on the government to take appropriate steps to ensure and protect the realization of the Human Right to accessible credit for the poor households.

Despite the high frequency of payday transactions and lack of objective empirical studies of the phenomenon, the industry is suffering from very poor public perception and rather strict legislation. The media is overfilled with horror stories of payday loan gone wrong and surveys show (RAIT, 2013) that the attitude of the 
respondents towards payday loan services are very negative. $34.3 \%$ evaluated them as very negative, $34.9 \%$ - rather negative and only $2.4 \%$ responded very positively. Presumably, because of such public pressure, the exceptions provided in the Consumer Credit Directive 2008/48/EC for loans up to $200 \mathrm{EUR}$; loans payable in 3 months term, or free of charge ${ }^{17}$ have not been transposed into the Law on Consumer Credit. The failure to harmonise law with the Directive is not that harmfull as current legislative initiatives. The application of $40 \%$ fit-for-all debt-to-income ratio, below which the lending is prohibited; initiative to lessen the usury cap from $200 \%$ to $36 \%$, which covers only $1 / 4$ of the operating costs, threatens to leave emergency credit market without lenders. That is, the poorest part of the Lithuanian households, ones that have the strongest claim to benefit from the Human Right to credit, will inevitably be excluded from the credit market.

Of course, recognizing the bilateral nature of transaction, bounded rationality of consumer and the Greed of lenders, some restrictions to access of credit may indeed protect the households from over-indebtedness. However, this has to be done with the punctilio of attention to the impact of such restrictions to ones that are on the cliff of poverty. The Government does not a priori know better what is best for the poor, at least not without carefull holistic evaluation of the effect that the access to credit has on the general welfare.

Finding fair balance between the Need and the Greed is extremely challenging, demanding time, resources and visionary insights into future. But the harshness of the legislative procedure shall not excuse the state institutions from their Constitutional duty to serve the people. What are needed as we have suggested, is the subjective evaluation techniques, measurement and means to diminish the transaction costs and fair process of transacting. However, we have to admit here that the field of discourse we have barely scratched above is far larger than the space we have to present it. Accordingly, much has been left for future theoretical development and empirical testing.

\section{Notes}

1 The phrase "we the people", well known from the preamble of the United States Constitution, is used here to suggest, that the market economy order originates from the People. This pertains to the value of individual rights and equality among all family members of society and suggests that in order to understand market economy, the unit of analysis shall be a person and drivers of his behavior.

2 For empirical evidence on the consumption and savings behaviour, see T. Bayoumi (1993) for example.

3 For excellent review see M. Hudon (2009).

4 Although we believe that exponential growth of frequency of transactions, "big bang" of data and widgets thereof, had made social em- beddedness changing not in $10^{2}-10^{3}$, but exponentially much faster.

5 See for e.g., Preamble of the Universal Declaration of Human Rights (UDHR); Preamble of International Covenant on Economic, Social and Cultural rights (ICESCR); Preamble of the Convention on the Rights of the Child (CRC); Preamble (a) of the Conventin on the Rights of Persons with Disabilities (CRPD); Article 21 of the Constitution of Lithuania; etc.

6 Using internet and/or telephone, a full transaction may be completed in less than $15 \mathrm{~min}$ utes. Moreover, the industry rapidly expands the network of physical places of access. The ability to provide application in the post 
stands or lottery terminals in stores creates bigger network than all mainstream credit offices combined.

7 According to the Bank of Lithuania (2012), the average loan amount is 653 LTL ( 189 EUR), which is borrowed for a 2.2 months term at $216 \%$ of APR.

8 The full list of consumer credit providers is available at <http://www.lb.lt/viesasis_vartojimo_ kredito_daveju_sarasas $>$ [accessed 2013-06-03].

9 According to the records of changes in shareholders or management structure, we may also suggest that the companies established before 2000 have switched previous activities to payday lending in the same $2008-2009$ period. It makes 20 of 27 (74.07\%) of start-ups in 2008-2009.

10 UAB "4Finance" (www.smscredit.lt and www. vivus.lt), UAB “MCB Finance” (www.credit24.lt) and UAB "Moment credit" (www.momentcredit. lt) have approximatedly $80 \%$ of the market.

11 These are: (1) total stock of debt or debt per capita; (2) proportion of households with net liabilities; (3) consumption to income ratio; (4) debt to income ratio; (5) debt to asset ratio;
(6) number of bankruptcies/arrears; (7) rate of credit delinquencies; (8) average liabilities per bankruptcy; and (9) number of households self-reporting to be over-indebted.

12 Realizing that the field of process mining is far larger than the space we have to explain it, we should stop with proclamation of the name, without any deeper insights into it, leaving this task for further researches.

13 Most of the time fairness and efectiveness coincide (Šimašius, 2002).

14 O. E. Williamson is admitted to be one of the most cited schollars in the social science (Pessali, 2006; Pessali, Fernández, 2012)

15 We adhere to the procedural approach to fairness, since it is in line with the proposition by O. E. Williamson (1985) to analyze transaction as a process when a good or service is transferred across a technologically separable interface.

16 See note 10.

17 Most of payday loan companies in Lithuania provide major discounts (up to $100 \%$ ) on interest for the first loan.

\section{References}

1. Aalst van der, W. M. P. et al. (2012). Process Mining Manifesto. In BPM 2011 Workshops proceedings. Lecture Notes in Business Information Processing. Springer-Verlag, pp. 1-19.

2. Aalst van der, W. M. P. (2011). Process mining: Discovery, Conformance and Enhancement of Business Processes. - Heidelberg, Dordrecht, London, New York: Springer, pp. 1-352.

3. Bar-Gill, O. (2007). Behavioral Economics of Consumer Contracts // The. Minn. L. Rev. No. 111, pp. 749-802.

4. Bayoumi, T. (1993). Financial Deregulation and Consumption in the United Kingdom // The Review of Economics and Statistics. Vol. 75, No. 3, pp. 536-539.

5. Ben-Shahar, O. (2004). Agreeing to Disagree: Filling Gaps in Deliberately Incomplete Contracts // John M. Olin Program in Law and Economics Paper. No. 04-002, pp. 1-39.

6. Betti, G., Dourmashkin, N., Rossi, M., Yin, Y. P. (2007). Consumer Over-indebtedness in the EU: Measurement and Characteristics //
Journal of Economic Studies. Vol. 34, No. 2, pp. 136-156.

7. Bhutta, N., Skiba, P., Tobacman, J. (2012). Payday Loan Choices and Consequences // Vanderbilt Law and Economics Research Paper. No. 12-30, pp. 1-35. doi: 10.2139/ssrn.2160947.

8. Bodenhorn, H. (2005). Usury Ceilings, Relationships and Bank Lending Behavior: Evidence from Nineteenth Century. - NBER Working Paper. No. 11734. Cambridge, MA: National Bureau of Economic Research, pp. 1-47.

9. Carrell, S., Zinman, J. (2008). In Harm's Way? Payday Loan Access and Military Personnel Performance, pp. 1-45.

10. Carter, R., Hodgson, G. M. (2006). The Impact of Empirical Tests of Transaction Cost Economics on the Debate on the Nature of the Firm // Strategic Management Journal. Vol. 27, No. 5, pp. 461-476.

11. Central Bank of the Republic of Lithuania (LCB) (2012). Vartojimo kredito rinkos apžvalga $2011 \mathrm{~m}$. Internet access: <http://www. 
lb.lt/vartojimo_kredito_rinkos_apzvalga_1> [accessed May 29, 2013].

12. Bank of Lithuania (2013). Vartojimo kredito rinkos apžvalga $2012 \mathrm{~m}$. Internet access: $<$ http://www.lb.lt/vartojimo_kredito_rinkos_ apzvalga_2012_m> [accessed July 3, 2013].

13. Bank of Lithuania (2013). Namų ūkių finansinès elgsenos apklausos apžvalga. Internet access: <http://www.lb.lt/apklausos> [accessed May 29, 2013)].

14. Coase, R. (1937). The Nature of the Firm // Economica. Vol. 4. pp. 386-405.

15. Coase, R. (1960). The Problem of Social Cost // The Journal of Law and Economics. Vol. 3, No. 1, pp. 1-44.

16. D’Alessio, G., Iezzi, S. (2013). Household OverIndebtedness: Definition and Measurement with Italian Data // Bank of Italy Occasional Paper. No. 149, pp. 1-22. doi: 10.2139/ ssrn.2243578.

17. Eggleston, K., Posner, E. A., Zeckhauser, R. J. (2000). Simplicity and Complexity in Contracts. - John M. Olin Program in Law and Economics Working Paper. No. 93. The Law School, The University of Chicago, pp. 1-45. doi:10.2139/ssrn.205391.

18. Epstein, R. (2006). Behavioral Economics: Human Errors and Market Corrections // U. CHI. L. REV. Vol. 73, No. 1, pp. 111-132.

19. European Banking Industry Committee (2011). Draft EBIC Response to the Financial Stability Board Consultation Paper on: Principles for Sound Residential Mortgage Underwriting Practices. Internet access: <http://www.eubic. org/position\%20papers.htm> [accessed May 29, 2013].

20. European Banking Industry Committee (2013). Ebic's Views on the Liikanen Report's Recommendations. Internet access: <http:// www.eubic.org/position \%20papers.htm> [accessed May 29, 2013].

21. European Commission (2001). Study of the problem of Consumer Indebtedness: Statistical Aspects. Internet access: <http://ec.europa. $\mathrm{eu} / \mathrm{consumers} / \mathrm{cons}$ _int/fina_serv/cons_ directive/> [accessed May 29, 2013].

22. European Commission (2008). Towards a Common Operational European Definition of Over-Indebtedness. Internet access: <http:// www.oee.fr/files/study_overindebtedness_ en.pdf> [accessed June 3, 2013].

23. European Commission (2010). Overindebtedness. New evidence from the EU-
SILC special module. Internet access: $<$ http:// ec.europa.eu/social/BlobServlet?docId $=6708 \&$ langId=en $>$, [accessed June 3, 2013].

24. Fritzdixon, K., Hawkins, J., Skiba, P. M. (2013). Dude, Where's My Car Title?: The Law, Behavior, and Economics of Title Lending Markets // University of Illinois Law Review. Forthcoming, pp. 1-50.

25. Gershman, J., Morduch, J. (2011). Credit Is Not a Right. Financial Access Initiative Research Framing Note. April, pp. 1-9.

26. Geyskens, I., Steenkamp, J. B. E. M., Kumar, N. (2006). Make, Buy, Or Ally: A Transaction Cost Theory Meta-Analysis // The Academy of Management Journal. Vol. 49, No. 3, pp. 519-543.

27. Hart, O., Moore, J. (1999). Foundations of Incomplete Contracts // The Review of Economic Studies. Vol. 66, No. 1, pp. 115-138.

28. Hill, C. A. (2009). Bargaining in the Shadow of the Lawsuit: A Social Norms Theory of Incomplete Contracts // Minnesota Legal Studies Research Paper. No. 08-46, pp. 1-38.

29. Hudon, M. (2009). Should Access to Credit be a Right? // Journal of Business Ethics. Vol. 84, No. 1, pp. 17-28.

30. Hudon, M., Sandberg, J. (2011). Towards a Theory of Fair Interest Rates on Microcredit. Working Papers CEB. No. 11-019, pp. 1-31.

31. Karlan, D., Zinman, J. (2010). Expanding Credit Access: Using Randomized Supply Decisions to Estimate the Impacts // Review of financial studies. Vol. 23, No. (1), pp. 1-45.

32. Macher, T. J., Richman, B. D. (2008). Transaction cost economics: An Assessment of Empirical Research in the Social Sciences // Business and Politics. Vol. 10, No. 1, pp. 1-85. doi: 10.2139/ssrn.924192.

33. McDougal, M., Lasswell, H., Chen, L. (1977). Human Rights and World Public Order: Human Rights in Comprehensive Context // Nw. UL Rev. Vol. 72, No. 2, pp. 227-307.

34. Meade, E. (2012). Responsible Lending: Irresponsible Regulation of Consumer Credit In New Zealand? - Dissertation. The University of Otago. New Zealand, pp. 1-64.

35. Melzer, B. T. (2009). The Real Costs of Credit Access: Evidence from the Payday Lending Market. - Kellogg School of Management, Northwestern University, pp. 1-51.

36. Modigliani, F., Brumberg, H. R. (1954). Utility Analysis and the Consumption 
Function: an Interpretation of Cross-section Data. In Kurihara, K. K., ed. Post-Keynesian Economics. - New Brunswick, NJ.: Rutgers University Press, pp. 388-436.

37. Modigliani, F., Brumberg, H. R. (1990). Utility Analysis and Aggregate Consumption Functions: an Attempt at Integration. In Abel, A., ed., The Collected Papers of Franco Modigliani: Volume2, The Life Cycle Hypothesis of Saving. Cambridge. - MA: The MIT Press, pp. 128-197.

38. Morgan, D. P., Strain, M. R. (2008). Payday Holiday: How Households Fare After Payday Credit Bans. - FRB of New York Staff Report. No. 309, pp. 1-47.

39. Morse, A. (2011). Payday Lenders: Heroes or Villains? // Journal of Financial Economics. Vol. 102 No. 1, pp. 28-44.

40. Nozick, R. (1974). Anarchy, State, and Utopia. Cambridge, MA: Blackwell Publishers Ltd, pp. 1-367.

41. Pessali, H. F. (2006). The Rhetoric of Oliver Williamson's Transaction Cost Economics // Journal of Institutional Economics. Vol. 2 No. 01, pp. 45-65. doi: 10.1017/ S1744137405000238.

42. Pessali, H., Fernández, R. (2012). Spreading the Word: Transaction Cost Economics in the Conversation ofEconomics// American Journal of Economics and Sociology. Vol. 71, No. 2, pp. 229-253. doi: 10.1111/j.15367150.2012.00834.x.

43. Peterson, C. L. (2008). Usury Law, Payday Loans, and Statutory Sleight of Hand: Salience Distortion in American Credit Pricing Limits // Minn. L. Rev. Vol. 92, No. 1110, pp. 1110-1165.

44. Posner, E. (1999). A Theory of Contract Law under Conditions of Radical Judicial Error. John M. Olin Program in Law \& Economics Working Paper. 2nd ser. No. 80. The Law School. The University of Chicago, pp. 1-39.

45. Posner, R. A. (2003). Economic Analysis of Law. - New York: Aspen Publishers, pp. 1-747.

46. Posner, R. A. (2004). The Law and Economics of Contract Interpretation. - John M. Olin Program in Law \& Economics Working Paper. 2nd ser. No. 229. The Law School. The University of Chicago, pp. 1-51.

47. RAIT (2013). Marketing Category and Brand Research 2013. Unpublished, pp. 1-81.

48. Rasmusen, E. (2001). A Model of Negotiation, Not Bargaining: Explaining Incomplete
Contracts. - In the Harvard John M. Olin Discussion Paper. No. 324. Cambridge, MA: Harvard Law School, pp. 1-52.

49. Reifner, U., Clerc-Renaud, S., Knobloch, M. R. (2009). Study on interest rate restrictions in the EU. - Final Report. Hamburg: iff, pp. $1-432$.

50. Rigbi, O. (2009). The Effects of Usury Laws: Evidence from the Online Loan Market. Job market paper. - Stanford University, pp. 1-42.

51. Ruester, S. (2010). Recent Developments in Transaction Cost Economics. - EE2 Working Paper. Resource Markets. No. WP-RM-18, pp. 1-47.

52. Rutherford, J. (2005). Usury: Necessary Evil or Evil Necessity? / In Neilson L. C., ed. The Future of Marketing's Past. Conference on Historical Analysis in Marketing Proceedings. Long Beach, CA, pp. 260-264.

53. Sen, A. (2009). The Idea of Justice. - Cambridge, MA: The Belknap Press of Harvard University Press, pp. 1-51.

54. Šimašius, R. (2002). Teisinis pliuralizmas. Dissertation. The Law University of Lithuania. Vilnius, pp. 1-28.

55. Statistics Lithuania (2011). Income and Living Conditions 2011. Internet access: <http://web. stat.gov.lt/lt/catalog/download_release/?id $=3883 \&$ download $=1 \&$ doc $=2153>\quad$ [accessed May 29, 2013].

56. Temin, P., Voth, H. J. (2004). Financial Repression in a Natural Experiment: Loan Allocation and the Change in the Usury Laws in 1714. - London: Centre for Economic Policy Research, pp. 1-30.

57. Vaišvila, A. (2004). Teisès teorija. - Vilnius. Justitia.

58. Weissbrodt, D., Fitzpatrick, J., Newman, F. (2001). International Human Rights: Law, Policy, and Process 9. 3d edition, pp. 774-775;

59. Williamson, O. E. (1975). Markets and Hierarchies: Analysis and Antitrust Implications: A Study in the Economics of Internal Organization. - London: Free Press, pp. 1-288.

60. Williamson, O. E. (1985). The Economic Institutions of Capitalism. - New York, NY: Free Press, pp. 15-38.

61. Williamson, O. E. (1998). Transaction Cost Economics: how it Works; where it is Headed // De economist. Vol. 146, No. 1, pp. 23-58.

62. Williamson, O. E. (2000). The New Institutional Economics: Taking Stock, Looking Ahead // 
Journal of Economic Literature. Vol. XXXVIII, No. 3, pp. 595-613.

63. Williamson, O. E. (2000). Why Law, Economics, and Organization? - Business and Public Policy Working Paper. No. 81. Berkeley: University of California, pp. 1-5.

64. Williamson, O., Tadelis, S. (2012). Transaction Cost Economics. Prepared for Gibbons R., Roberts J, eds. Handbook of Organizational Economics. Princeton University Press, pp. 1-55.

65. Wilson, B. J., Findlay, D. W., Meehan Jr., J. W., Wellford, C. P., Schurter, K. (2010).
An Experimental Analysis of the Demand for Payday Loans. The B.E // Journal of Economic Analysis \& Policy. Vol. 10, No. 1. doi:10.2202/1935-1682.2563.

66. Yunus, M. (2006). Nobel Lecture. Internet access: <http://www.nobelprize.org/nobel_ prizes/peace/laureates/2006/yunus-lecture. html> [accessed May 29, 2013].

67. Zinman, J. (2010). Restricting Consumer Credit Access: Household Survey Evidence on Effects around the Oregon Rate Cap // Journal of Banking \& Finance. Vol. 34, No. 3, pp. 546-556.

The paper submitted: August 14, 2014

Prepared for publication: September 10, 2014

\section{Valdonė DARŠKUVIENĖ, Paulius ASTROMSKIS}

\section{MAŽIEJI VARTOJIMO KREDITAI LIETUVOJE: POŽIŪRIAI IR IŠŠŪKIAI}

\section{S a n t r a u k a}

Mažųjų vartojimo kreditų rinka Lietuvoje išsivystẻ ir greitai išaugo ekonominio sunkmečio metu, t. y. 2008-2009 metais, iš esmès dèl likvidumo problemų ir sugriežtejuusio skolinimo iš tradicinių šaltinių. Tačiau nežiūrint didelio populiarumo, mažieji vartojimo kreditai igijo prastą reputaciją dèl kaltinimų amoraliu ir neatsakingu skolinimu, iliustruojant šiuos kaltinimus vaizdingomis nesèkmingų paskolų istorijomis. Atsakydamos i viešą kritiką ir reguliuotojų iniciatyvas, paskolų davejjai paprastai stengiasi pasiteisinti didelemis sandorio sąnaudomis ir nauda vartotojui turèti prieinamą paskutinès vilties paskolą.

Kitaip tariant, mažųjų vartojimo kreditų problema kyla iš klasikinès ir natūralios įtampos tarp kredito poreikio, su didžiausia svarba neturtingiems, bei finansų ịstaigų godumo. Poreikiai ir godumas yra (ir visada buvo) vartojimo finansų yin ir yang. Ši ịtampa atkreipè ne tik žiniasklaidos ir reguliuotojų dèmesị. Mokslininkai čia taip pat rado daug iššūkių teoriniams ir empiriniams tyrimams. Tačiau mažųjų vartojimo kreditų fenomenas, nors ir kontroversiškas, yra per mažai ištirtas, ypač Lietuvos kontekste.

Atitinkamai pagrindinis motyvas, lèmęs šio straipsnio pobūdị ir struktūrą, yra iš esmès metodologinis. Čia keliami diskusiniai klausimai vartojimo kreditų srityje, kurie Lietuvos moksle nebuvo tyri- nèti. Dideli teisès, ekonomikos ir vadybos iššūkiai yra palikti tolimesniam teoriniam pagrindimui ir empiriniam patikrinimui. Atitinkamai, šio straipsnio tikslas yra pasiūlyti analitinị požiūrị ì kredito prieinamumo problemas mažųjų vartojimo kreditų srityje ir apibūdinti Lietuvos kontekstą tolimesniems tyrinejimams. Tad šis straipsnis prisideda prie žinių ir supratimo apie teisingą pusiausvyrą tarp vartotojų poreikių ir kreditorių godumo.

Šio straipsnio dalyje, skirtoje poreikiams, klausiame ar kreditas turi būti pripažintas ir laikomas žmogaus teise per se. Naudojantis Nobelio premijos laureato Muhammad Yunus (2006) išvystytu požiūriu i skurdo mažinimą, atsakymų i ši klausimą yra ieškoma, remiantis plačiai išvystytu žmogaus orumo principu bei pakankamo pragyvenimo lygio garantijų butinumu. Nors ir su kritika, tačiau straipsnyje pateikiama svarių argumentų, palaikančių pasiūlymą, jog neturtingi namų ūkiai turi rimtą pagrindą naudotis kreditu kaip teise. Dar daugiau, apibendrinus situaciją Lietuvos namų ūkiuose, straipsnyje pateikiami nerimą keliantys duomenys kurie, mūsų nuomone, paaiškina mažųjų vartojimo kreditų populiarumą ir priežastis, kodèl kredito prieinamumas šiems namų ūkiams yra svarbiau už kainą.

Šio straipsnio dalyje, skirtoje godumui, išskiriame ir atskirai aptariame atsakingo skolinimo ir pa- 
lūkanų dydžio klausimus. Išnagrinèjus gerai žinomą problematiką, susijusią su prasiskolinimo apibrěžimu ir matavimu, straipsnyje daroma išvada, jog tinkamiausias yra subjektyvusis požiūris ị prasiskolinimą, ir siūlomas metodas jam matuoti. Palūkanų dydžio problema taip pat yra dvilypè: viena vertus, susijusi su sandorio sąnaudų klausimais, o antra vertus, su priimtinu jų dydžiu. Naudojantis sandorio sąnaudų teorijos logika, išvystyta dviejų Nobelio premijos laureatų R. Coase (1937) ir O. E Williamson (1975), straipsnyje glaustai aprašomi pagrindiniai kintamieji ir požiūris ị tai, kaip juos išmatuoti. Sprendžiant priimtino palūkanų dydžio klausimą straipsnyje yra kritikuojami vienodo dydžio ir visoms situacijoms taikytini apribojimai ir palaikomas procedūrinis po- žiūris ị teisingumą, nors vèlgi - ne be tam tikros kritikos. Tai aptarus, straipsnyje yra glaustai pateikiami tam tikri finansiniai mažuju vartojimo kreditu tiekejju veiklos rezultatų finansiniai duomenys bei daromos išvados, jog pelno maržų dydis gali būti pagrịstas blogų kreditų tendencijomis bei administravimo sąnaudomis. Siekiant atsakyti $\mathfrak{i}$ iškeltus probleminius klausimus, tolimesni tyrimai mažujų vartojimo kreditų srityje turètų orientuotis ị neapibrèžtumo ir riboto racionalumo mažinimo aspektus ex ante sandorių srityje bei oportunizmo ir turto specifiškumo aspektus ex post sandorių atveju. Pastarasis tyrimų aspektas būtų itin aktualus formuojant reguliuotojo vaidmenį ir sprendimų pagrindimą mažųjų vartojimo kreditų atveju. 